\title{
Previsões e ilusões
}

\section{FÁBIO KONDER COMPARATO}

$\mathrm{O}$ GRANDE ENIGMA do Manifesto Comunista é o fato de haver feito previsões rigorosamente exatas sobre a evolução da economia mundial, com base numa falsa premissa. Dito de outra forma, verificamos hoje com surpresa, um século e meio após, que, apesar do erro de diagnóstico e do consequiente desacerto da terapêutica proposta, grande parte do prognóstico evolutivo da moléstia capitalista foi cumpridamente realizado.

A análise estrutural e funcional do capitalismo feita - por Marx e Engels com mão de mestre, resistiu à prova da evolução histórica e permanece, ainda hoje, inatacável. Senão, vejamos.

\section{Impessoalização das relações econômicas}

"Em toda parte onde chegou ao poder, a burguesia destruiu o conjunto das relaçôes feudais, patriarcais ou idílicas", substituindo-as pelo "puro interesse", ou a insensibilidade do "pagamento à vista".

Essa impessoalização econômica correspondeu, estrutural e historicamente, à impessoalidade da lei, fundamento constitucional do Estado modemo a partir da Revoluçáo Francesa. À divisão estamental do direito antigo - com estatutos separados para o clero, a nobreza e o povo -, substituiu-se a homogeneidade do sistema jurídico nacional, em que todos os indivíduos (abstratamente considerados) são iguais perante a lei.

A evolução da grande empresa capitalista obedeceu à mesma lei da impessoalidade crescente. A forma jurídica que se impôs desde o século XIX como o modelo ideal para a macroempresa foi a da sociedade justamente denominada anônima, em que o capital social é dividido em fraçóes-alíquotas de valor igual, perfeitamente intercambiáveis: as açôes.

A partir da segunda metade do século XX e em toda parte, a tecnoestrutura gerencial tendeu a suplantar, ao cabo de poucas geraçóes, a dominação pessoal do patrão pela gestão empresarial coletiva. Nos Estados Unidos, já nos anos 30, Berle e Means mostraram o surgimento de um controle gerencial (management control) das grandes companhias, inteiramente destacado da propriedade do capital (1). 
Patrimonialização das relações sociais

"A burguesia despojou de sua santa auréola todas as atividades até então veneráveis e piedosamente respeitadas."

"A burguesia dissolveu a dignidade da pessoa no valor de troca, e substituiu às inúmeras franquias, garantidas como direito adquirido, uma liberdade única e sem consciência: o livre câmbio."

Às vésperas da Revolução Industrial, que desencadeou o processo histórico da ascensão burguesa, Montesquieu ainda pôde classificar os regimes políticos segundo os princípios fundamentais da honra, da virtude ou do temor (2). A civilização capitalista, em contraste, substituiu em pouco mais de um século a honra, a liberdade, a virtude, o patriotismo e a fé religiosa pelo valor mercantil das coisas e dos homens. As relaçóes sociais, de qualquer natureza, tornaram-se apreciáveis em dinheiro. Até a capacidade política, na primeira fase da democracia burguesa, fundou-se na renda monetária, pelo mecanismo do voto censitário.

\section{Desmaterialização e concentração da propriedade capitalista}

"A burguesia submeteu o campo à dominação da cidade".

"Para existir e dominar, a classe burguesa tem necessidade de algo essencial: a acumulação da riqueza em mãos dos particulares, a formação e o crescimento do capital".

A sociedade feudal fundava-se na propriedade da terra, que assegurava poder político. Nas civilizaçōes de base agrária, sempre vigorou o princípio res mobilis, res vilis.

Já nas cidades mercantis da Baixa Idade Média, ao contrário, a riqueza e o poder político passaram a ser medidos em termos de acumulação de metais preciosos, jóias, mercadorias ou dinheiro.

O capitalismo industrial do século XIX concentrou os meios de produção em fábricas, minas e laboratórios. Mas na economia pós-industrial do presente, a dominação capitalista funda-se na titularidade de contas bancárias, papéis negociáveis em Bolsa ou no mercado de balcão e aplicações em fundos de investimento.

Toda essa parafernália escritural e contábil veio facilitar enormemente a criação de macroempresas. Em 1997 as fusōes e aquisiçōes de controle empresarial, em todo o mundo, atingiram a cifra de um trilhão e seiscentos milhões de dólares, ou seja, o dobro do PIB brasileiro. $O$ faturamento anual da General 
Motors, da Exxon e da Toyota é hoje superior, respectivamente, ao PNB da Dinamarca, da Noruega e de Portugal.

\section{Desestabilização de todas as instituiçóes}

“Tudo o que é permanente e estável volatiliza-se (Alles Ständische und Stehende verdampft)".

Duas das quatro liberdades invocadas pelo presidente Roosevelt em seu famoso discurso de 6 de janeiro de 1941, como bases para a reconstrução do mundo futuro, eram a libertação da necessidade e a libertação do medo (freedom from want e freedom from fear).

Meio século depois, porém, com o desaparecimento do espectro comunista, a liquidação do Estado social tende a levar ao paroxismo a sensação de insegurança de todos os povos diante dos velhos riscos do desemprego, da fome, da doença ou da velhice.

\section{A globalização}

"A grande indústria engendrou o mercado mundial, que a descoberta da América havia preparado."

"Ao explorar o mercado mundial, a burguesia deu uma forma cosmopolita à produçáo e ao consumo de todos os países."

Com a culminação atual do processo de mundialização da economia, iniciado pela descoberta da América, como o Manifesto bem assinalou, parece óbvio, aplicando-se uma chave de interpretação marxista, que nos encontramos hoje em plena crise: a contradição entre o caráter universal das forças produtivas e a organização ainda predominante nacional das relaçôes econômicas. O país hegemônico no plano mundial - os Estados Unidos - resistem (por quanto tempo?) à reconstrução da ordem internacional para a superação dessa crise, na medida que ela implicaria, inevitavelmente, a limitação de sua soberania.

Ora, se todas essas previsōes se realizaram com a maior precisão nos últimos 150 anos, não deixa de ser perturbador verificar que elas foram justificadas por Marx e Engels a partir de uma premissa inteiramente falsa: a suposição de que “à medida que o capital se desenvolve, assiste-se ao desenvolvimento do proletariado, da classe dos trabalhadores modernos, que somente sobrevivem na medida em que encontram trabalho, e que só encontram trabalho na medida em que seu trabalho faz crescer o capital". Ou seja, o falso pressuposto de 
que "a condiçáo (de existência) do capital é o trabalho assalariado" (Die Bedingung des Kapitals ist die Lohnarbeit).

A evolução econômica da segunda metade do século XX demonstrou a cabal incorreção dessa análise. O capitalismo contemporâneo tende a desvincular por completo a produção do trabalho e o lucro da produção. Não só a produtividade capitalista funda-se, hoje, na reduçáo crescente do trabalho assalariado (e não apenas na apropriação da mais-valia), como ainda a lucratividade empresarial depende cada vez menos da produção de bens ou serviços. A concentração de capital no setor puramente especulativo - jogos de bolsa ou operações monetárias - é, hoje, incomparavelmente maior do que nos setores de produção industrial, distribuição de bens e prestação de serviços; sem falar, obviamente na agricultura. Diariamente, as transaçôes mundiais em câmbio, valores mobiliários ou nos mercados de futuros movimentam em média um trilhão e meio de dólares, dos quais apenas $1 \%$ é aplicado em investimentos produtivos.

Como previra Hannah Arendt há 40 anos (3), "o que se nos depara é a possibilidade de uma sociedade de trabalhadores sem trabalho, isto é, sem a única atividade que lhes resta." E concluiu com razáo: "Certamente, nada poderia ser pior".

\section{Notas}

1 A sua obra The modern corporation and private property teve sua primeira edição em 1932.

2 De l'esprit des Lois, livro terceiro.

3 A condição humana (Forense-Universitária, Salamandra Consultoria Editorial, Editora da Universidade de São Paulo, 1981, p. 13). A ediçáo original inglesa, sob o título The human condition, foi publicada em Chicago no ano de 1958.

Fábio Konder Comparato, doutor em Direito pela Universidade de Paris, é professor titular da Faculdade de Direito da Universidade de São Paulo. 